\title{
The $\mathrm{N}$-terminal domain of the human elF2 $\beta$ subunit and the CK2 phosphorylation sites are required for its function
}

\author{
Franc LLORENS ${ }^{1}$, Anna DUARRI, Eduard SARRÓ, Nerea ROHER, Maria PLANA and Emilio ITARTE \\ Departament de Bioquímica i Biologia Molecular, Unitat de Bioquímica de Ciències, Universitat Autònoma de Barcelona, Edifici Cs, Campus de Bellaterra, \\ 08193 Bellaterra, Barcelona, Spain
}

\begin{abstract}
CK2 (protein kinase CK2) is known to phosphorylate eIF2 (eukaryotic translation initiation factor 2) in vitro; however, its implication in this process in living cells has remained to be confirmed. The combined use of chemical inhibitors (emodin and apigenin) of CK2 together with transfection experiments with the wild-type of the K68A kinase-dead mutant form of CK $2 \alpha$ evidenced the direct involvement of this protein kinase in eIF $2 \beta$ phosphorylation in cultured HeLa cells. Transfection of HeLa cells with human wild-type eIF $2 \beta$ or its phosphorylation site mutants showed $\mathrm{Ser}^{2}$ as the main site for constitutive $\operatorname{eIF} 2 \beta$ phosphorylation, whereas phosphorylation at $\operatorname{Ser}^{67}$ seems more restricted. In vitro phosphorylation of $\operatorname{eIF} 2 \beta$ also pointed to $\mathrm{Ser}^{2}$ as a preferred site for CK2 phosphorylation. Overexpression of the $\operatorname{eIF} 2 \beta$ S2/67A mutant slowed down the rate of protein synthesis stimulated by serum, although less markedly than the overexpression of the $\Delta 2-138 \mathrm{~N}$-terminal-truncated form of
\end{abstract}

eIF2 $\beta$ (eIF2 $\beta$-CT). Mutation at $\operatorname{Ser}^{2}$ and $\operatorname{Ser}^{67}$ did not affect eIF2 $\beta$ integrating into the eIF2 trimer or being able to complex with eIF5 and CK $2 \alpha$. The eIF2 $\beta$-CT form was also incorporated into the eIF2 trimer but did not bind to eIF5. Overexpression of eIF2 $\beta$ slightly decreased HeLa cell viability, an effect that was more evident when overexpressing the eIF $2 \beta$ S2/67A mutant. Cell death was particularly marked when overexpressing the eIF $2 \beta$-CT form, being detectable at doses where eIF2 $\beta$ and eIF2 $\beta$ S2/67A were ineffective. These results suggest that $\operatorname{Ser}^{2}$ and $\operatorname{Ser}^{67}$ contribute to the important role of the N-terminal region of $\operatorname{eIF} 2 \beta$ for its function in mammals.

Key words: eukaryotic translation initiation factor 2 (eIF2), HeLa cells, human eIF $2 \beta$ subunit, protein interaction, protein kinase CK2, protein phosphorylation.

\section{INTRODUCTION}

Translation initiation in eukaryotes requires the participation of multiple protein components that must form transient, specific complexes following a fixed and precise sequence [1,2]. Some of the eIFs (eukaryotic translation initiation factors), such as eIF2, intervene at different stages of translation initiation, due to the presence in its structures of different domains, each one involved in specific functions. The conventional form of eIF2 is a trimer made of one copy of each of the three different subunits (eIF $2 \alpha$, eIF $2 \beta$ and eIF $2 \gamma$ ). Of these subunits, eIF $2 \alpha$ is well known to play a key regulatory role in translation initiation. Phosphorylation on its $\operatorname{Ser}^{51}$ by different eIF2 $\alpha$ kinases [1-4] leads to it binding tightly to the non-catalytic subunits of eIF2B, sequestering it in an inactive complex. eIF2B is the GEF (guanine nucleotide-exchange factor) protein that catalyses the GDP/GTP exchange in eIF2, a crucial event that allows eIF2 to participate in a new round of translation initiation. The eIF $2 \gamma$ subunit is the central component in assembling the eIF2 trimer, bridging between eIF2 $\alpha$ and eIF $2 \beta$. It contributes to the G-protein-like properties of eIF 2 and together with the eIF2 $\beta$ subunit contributes to Met-tRNAiMet (initiator methionine transfer RNA) binding $[5,6]$.

Previous studies based on genetic approaches with yeast or using recombinant mammalian proteins have shown that eIF2 $\beta$ subunit is responsible for many of the interactive properties characteristic of eIF2. The eIF2 $\beta$ subunit binds to mRNA [7] as well as to the catalytic subunit of eIF2B $(\mathrm{eIF} 2 \mathrm{~B} \varepsilon)[8,9]$ and to eIF5 (which acts as a GTPase-activating protein) $[9,10]$. Moreover, eIF2 $\beta$ binds directly to TIF32 (transcriptional intermediary factor 32)/eIF3a [11] and eIF2 $\beta$ binding to eIF5 potentiates the asso- ciation of the latter with Nip1/eIF3c, which helps to integrate the ternary complex into the multifactor complex [12]. In addition, eIF $2 \beta$ binds to the adaptor protein Nck-1 [13] and this binding prevents the phosphorylation of eIF $2 \alpha$ and the subsequent arrest of translation in response to endoplasmic reticulum stress [14]. We have recently shown that eIF2 $\beta$ also binds to CK2 (protein kinase CK2), an enzyme known to phosphorylate in vitro different eIFs, including eIF2, and ribosomal proteins [15], and that the binding of eIF $2 \beta$ to the free catalytic subunit of $\mathrm{CK} 2(\mathrm{CK} 2 \alpha)$ inhibits its activity in protein substrates [16].

The functional and structural analyses of $\operatorname{eIF} 2 \beta$ have evidenced that it contains three different regions: the $\mathrm{N}$-terminal, the central and the $\mathrm{C}$-terminal regions $[17,18]$. The central region contains the binding site to eIF2 $\gamma$ [19], whereas the C-terminal region contains a zinc-finger motif that contributes to mRNA binding and start-site selection during the scanning process in yeast [20]. The central/Cterminal regions also contain the binding sites for CK2, whereas the phosphorylation sites for this protein kinase are located in the N-terminal region. The presence of three lysine blocks and in vitro phosphorylation sites for protein kinase CK2 and PKC (protein kinase $\mathrm{C}$ ) are characteristic of the $\mathrm{N}$-terminal region of mammalian $\operatorname{eIF} 2 \beta$ [21]. The lysine blocks are conserved in yeast and participate in binding to eIF5, eIF2B $\varepsilon$ and mRNA [7,9]. In yeast, deletion of the lysine blocks compromises cell growth, which points to an important role for this structural feature [7]. Whether these cell growth effects are also exerted on mammalian cells has not yet been explored.

Phosphorylation of eIF $2 \beta$ in vitro and in vivo has been known for almost three decades [22,23]. The sites phosphorylated in vitro on mammalian eIF2 $\beta$ have been mapped at $\operatorname{Ser}^{2}, \operatorname{Ser}^{67}$

Abbreviations used: CK2, protein kinase CK2; DMEM, Dulbecco's modified Eagle's medium; elF, eukaryotic translation initiation factor; FBS, fetal bovine serum; HA, haemagglutinin; hr, human recombinant; Met-tRNAiMet, initiator methionine tRNA; Ni-NTA, Ni²+nitrilotriacetate; PKC, protein kinase C; PP2A, protein phosphatase 2A; PP2Ac, catalytic subunit of the PP2A.

1 To whom correspondence should be addressed (email Franc.llorens@uab.es). 
(both targeted by CK2), $\mathrm{Ser}^{13}$ (targeted by PKC) and $\mathrm{Ser}^{218}$ [targeted by PKA (protein kinase A)] [21]. eIF2 $\beta$ is also a substrate for DNA-PK (DNA protein kinase) [24], although the phosphorylation site(s) for this kinase have not been identified yet. The studies on the phosphorylation of eIF $2 \beta$ in mammalian cells have shown that it varies under different conditions such as heat shock [25], serum deprivation [26], diabetes [27] and birth [28]. Yeast eIF2 is also a phosphoprotein, but in this case phosphorylation by CK2 in vitro takes place on its eIF2 $\alpha$ subunit but not on its eIF2 $\beta$ subunit $[29,30]$. Specific phosphorylation by CK2 at the eIF2 $\alpha$ subunit has also been reported for eIF2 from Artemia salina [31] and sea urchin [32].

Initial studies on the functional consequences of mammalian eIF $2 \beta$ phosphorylation for protein synthesis showed that it did not affect the ability of eIF2 to form the ternary complex with GTP and Met-tRNAiMet [33]. However, later on, it was observed that phosphorylation of eIF $2 \beta$ by CK2 decreases the affinity of GDP binding to eIF2 [34]. The mutagenic approach has proven to be very useful for defining $\mathrm{Ser}^{712} / \mathrm{Ser}^{713}$ as the constitutive CK2 phosphorylation sites in the eIF2B $\varepsilon$ subunit and for determining that it is required for the interaction with eIF2 in vivo [35], which provides an answer to the discrepancy in the results obtained in previous studies using endogenous phosphorylated eIF2B [3537].

In the present work, we studied the phosphorylation of human eIF2 $\beta$ in vivo and the relevance of the main phosphorylation sites and of the entire N-terminal domain of eIF2 $\beta$ in its interaction with some partners, in protein synthesis and in cell viability. Moreover, the role of CK2 in the basal phosphorylation of this subunit has been explored by using chemical inhibitors and a CK2 mutant that directly alters CK2 activity within the cell [38]. The results provide strong support for CK2 being involved in the basal phosphorylation of eIF2 $\beta$. They show that almost all of the cellular eIF2 $\beta$ is phosphorylated in $\mathrm{Ser}^{2}$, whereas phosphorylation in $\mathrm{Se}^{67}$ is more restricted and that mutation at these sites alters eIF $2 \beta$ properties, although less drastically than the truncation of the entire $\mathrm{N}$-terminal domain.

\section{EXPERIMENTAL}

\section{Reagents and antibodies}

Apigenin, emodin and anti- $\mathrm{His}_{6}$ antibody were obtained from Sigma, anti-eIF2 $\alpha$ and the catalytic subunit of the PP2A (protein phosphatase 2A) phosphatase were from Cell Signaling Technology, anti-CK2 $\alpha$ and anti-eIF5 were from Santa Cruz Biotechnology and anti-eIF2 $\alpha$ was from Cell Signaling Technology. The anti-eIF $2 \beta$ antibody was raised in rabbits immunized with the recombinant protein, and the immunoglobulin fraction was obtained from sera by Protein A-agarose chromatography (Amersham Biosciences). Anti-eIF2 $\gamma$ antibody was raised in rabbits against the human eIF2 $\gamma$ peptide VGQEIEVRPGIVSK. Anti-HA (haemagglutinin; 12CA5) antibody was from Roche. $\left[\gamma-{ }^{32} \mathrm{P}\right] \mathrm{ATP}$ and $\left[{ }^{32} \mathrm{P}\right] \mathrm{P}_{\mathrm{i}}$ were from Amersham Biosciences.

\section{Plasmids, protein expression and purification}

The catalytic (CK2 $\alpha)$ and regulatory (CK2 $\beta)$ subunits of human $\mathrm{CK} 2$, and the wild-type and mutated forms of the $\beta$-subunit of human eukaryotic initiation factor 2 cloned in $\mathrm{pQE}-30$ vector were expressed in Escherichia coli and purified as $\mathrm{His}_{6}$-tagged fusion proteins by Ni-NTA $\left(\mathrm{Ni}^{2+}\right.$-nitrilotriacetate)-agarose chromatography as described previously [16]. Amino acid substitutions were made by PCR oligonucleotide site-directed mutagenesis with the Stratagene kit according to the manufacturer's instructions. In all cases, mutations were confirmed by DNA sequencing. pCMV-HA or pCMV mammalian expression vectors (ClonTech) encoding N-terminal HA-tagged eIF2 $\beta$ and CK2 $\alpha$ respectively were made as described previously by subcloning from the $\mathrm{pQE}-30$ vectors (Qiagen) [16].

\section{Cell culture and transfection}

HeLa cells were grown in DMEM (Dulbecco's modified Eagle's medium) with $4.5 \mathrm{~g} / \mathrm{l}$ glucose supplemented with $10 \%$ (v/v) FBS (fetal bovine serum). Incubation was at $37{ }^{\circ} \mathrm{C}$ in a humidified atmosphere containing $5 \% \mathrm{CO}_{2}$. Cells were washed twice with cold PBS and lysed for $15 \mathrm{~min}$ on ice with lysis buffer A (50 mM Tris/HCl, pH 7.5, $100 \mathrm{mM} \mathrm{NaCl}, 0.1 \%$ Nonidet P40, $50 \mathrm{mM} \beta$ glycerolphosphate, $2 \mathrm{mM} \mathrm{PP}_{\mathrm{i}}, 25 \mathrm{mM} \mathrm{NaF}, 1 \mathrm{mM} \mathrm{Na}_{3} \mathrm{VO}_{4}, 1 \mathrm{mM}$ PMSF and $1 \mu \mathrm{g} / \mathrm{ml}$ each of leupeptin, pepstatin, benzamidine and aprotinin). Lysates were centrifuged at $12000 \mathrm{~g}$ for $30 \mathrm{~min}$ at $4{ }^{\circ} \mathrm{C}$ in an Eppendorf microfuge and supernatants were used for the assays. For cell transfection, cells were seeded at $0.2 \times 10^{6}$ cells/ $\mathrm{ml}$ and on the next day transfected with Lipofectamine ${ }^{\mathrm{TM}}$ Plus (Invitrogen) according to the manufacturer's instructions. After $3 \mathrm{~h}$, the complete medium was re-established overnight and cells were lysed as described above.

\section{Immunoprecipitation}

For transfected HA-eIF2 $\beta$, protein G-Sepharose $(10 \mu \mathrm{l})$, equilibrated with lysis buffer A, was incubated with $4 \mu \mathrm{g}$ of antiHA antibody. HeLa cell extract protein $( \pm 500 \mu \mathrm{g})$ was added and incubated for $2 \mathrm{~h}$ at $4{ }^{\circ} \mathrm{C}$ on shaking. The immunocomplexes were washed twice with lysis buffer A plus $0.5 \mathrm{M} \mathrm{NaCl}$ and once with lysis buffer A. Proteins attached to the beads were eluted with SDS/PAGE sample buffer $[0.5 \mathrm{M}$ Sucrose, $10 \%(\mathrm{w} / \mathrm{v})$ SDS, $300 \mathrm{mM}$ Tris/ $\mathrm{HCl}, 10 \mathrm{mM}$ EDTA, $250 \mathrm{mM}$ DTT (dithiothreitol) and $0.05 \%(\mathrm{w} / \mathrm{v})$ Bromophenol Blue], subjected to SDS/PAGE, transferred on to PVDF membranes and probed with the indicated antibodies or subjected to autoradiography as indicated.

\section{Pull-down assay}

$\mathrm{His}_{6}$-tagged eIF2 $\beta$, eIF2 $\beta$-NT (1-137) or eIF2 $\beta$-CT (138-333) $(1 \mu \mathrm{g}$ each) was mixed with $500 \mu \mathrm{g}$ of HeLa cell extract, previously precleared with Ni-NTA-agarose $(1: 1 ; 20 \mu \mathrm{l})$ (Qiagen) for $1 \mathrm{~h}$ at $4{ }^{\circ} \mathrm{C}$ in lysis buffer A. A slurry of Ni-NTA-agarose $(1: 1$; $20 \mu \mathrm{l})$ was added and left for $1 \mathrm{~h}$ at $4^{\circ} \mathrm{C}$ under gentle shaking. Samples were centrifuged at $12000 \mathrm{~g}$ for $5 \mathrm{~min}$ at $4{ }^{\circ} \mathrm{C}$ in an Eppendorf microfuge to sediment the $\mathrm{His}_{6}$-tagged proteins/NiNTA-agarose-complexes. Beads were washed with lysis buffer A three times and proteins were eluted with SDS/PAGE sample buffer and subjected to SDS/PAGE, transferred on to PVDF membranes and probed against indicated antibodies.

\section{$\left.{ }^{32} \mathrm{P}\right] \mathrm{P}_{\mathrm{i}}$ cell labelling}

HeLa cells were grown as described previously and maintained in phosphate-free medium for $1 \mathrm{~h}$. Cells were then grown in the presence of $0.5 \mathrm{mCi}$ of $\left.{ }^{32} \mathrm{P}\right] \mathrm{P}_{\mathrm{i}}$ for $4 \mathrm{~h}$. Where indicated, CK2 inhibitors apigenin $(40 \mu \mathrm{M})$ or emodin $(40 \mu \mathrm{M})$ were added to the assay during the labelling time. Cells were lysed with extraction buffer [50 mM Tris/ $\mathrm{HCl}(\mathrm{pH} 7.5), 150 \mathrm{mM} \mathrm{NaCl}, 1 \%$ Triton X-100, $25 \mathrm{mM} \mathrm{NaF}, 1 \mathrm{mM} \mathrm{Na} \mathrm{VO}_{4}$ and $1 \mu \mathrm{g} / \mathrm{ml}$ each of aprotinin, pepstatin, leupeptin and benzamidine] and proteins were immunoprecipitated as described before. Samples were loaded onto SDS/PAGE, transferred on to PVDF membranes and subjected to autoradiography. A sample of the cell extract was probed for anti-HA antibody to ensure equal amounts of transfected protein into the assay. 


\section{$\left[{ }^{35}\right.$ S]Methionine/cysteine cell labelling}

For protein synthesis measurements, HeLa cells were serumstarved with DMEM containing $0.5 \%$ FBS. After $24 \mathrm{~h}$, cells were maintained in DMEM containing $0.5 \%$ dialysed FBS lacking methionine/cysteine for $1 \mathrm{~h}$, and labelling was carried out by addition of $10 \%$ dialysed FBS containing $\left[{ }^{35} \mathrm{~S}\right]$ methionine/cysteine $(12.5 \mu \mathrm{Ci} / \mathrm{ml})$ at the indicated times. Cells were lysed as described above and protein was precipitated with $12 \%(\mathrm{w} / \mathrm{v})$ ice-cold trichloroacetic acid containing $10 \mathrm{mM}$ methionine/cysteine. Precipitated protein was washed twice with $5 \%$ ice-cold trichloroacetic acid and resuspended in $50 \mathrm{mM}$ Tris/ $\mathrm{HCl}$ (pH 7.5), $2 \%$ (v/v) Nonidet P40 and $1 \%$ SDS. Samples were boiled for $5 \mathrm{~min}$ at $100^{\circ} \mathrm{C}$ and spotted in triplicate on $3 \mathrm{MM}$ filters. The filters were washed three times with $10 \%$ trichloroacetic acid, once with acetone, air dried and subjected to liquid scintillation.

\section{Phospho amino acid analysis}

Phospho amino acid analyses of human recombinant eIF2 $\beta\left(\mathrm{His}_{6}-\right.$ eIF2 $\beta$ ) phosphorylated by CK2 or in vivo phosphorylated and immunoprecipitated eIF2 $\beta$ (HA-eIF $2 \beta$ ) were performed using one-dimensional analysis. The PVDF membranes containing the radiolabelled eIF $2 \beta$ band (5000 c.p.m.) were located by autoradiography, excised and transferred to a microcentrifuge tube. Protein was then hydrolysed in $0.2 \mathrm{ml}$ of $6 \mathrm{M} \mathrm{HCl}$ for $1 \mathrm{~h}$ at $110^{\circ} \mathrm{C}$. The sample was centrifuged, and the supernatant was freeze-dried and resuspended in $10 \mu \mathrm{l}$ of a mixture of phosphoserine, phosphothreonine and phosphotyrosine $(1 \mathrm{mg} / \mathrm{ml}$ each). The samples were then spotted on a thin-layer cellulose plate and subjected to electrophoresis at $1100 \mathrm{~V}$ for $40 \mathrm{~min}$ in pyridine acetate buffer ( $\mathrm{pH} 3.5$ ) (water/acetic acid/pyridine, 945:50:5, by vol.) in a water-cooled system. The plate was dried and sprayed with acetone plus $1 \%(\mathrm{w} / \mathrm{v})$ ninhydrin to localize the phospho amino acid standards. ${ }^{32} \mathrm{P}$-labelled amino acids on the dried plates were detected by autoradiography.

\section{CK2 activity assay}

HeLa cell extracts were lysed after treatments as described above and $5 \mu \mathrm{g}$ of cell extract protein was used to phosphorylate $0.2 \mathrm{mM}$ specific CK2 peptide (RRRAADSDDDDD) in the presence of $125 \mu \mathrm{M}\left[\gamma_{-}{ }^{32} \mathrm{P}\right] \mathrm{ATP}$ and kinase buffer $(50 \mathrm{mM}$ Tris/HCl, $\mathrm{pH} 7.5$, $1.5 \mathrm{mM}$ EGTA, $25 \mathrm{mM} \mathrm{MgCl}_{2}, 10 \mathrm{mM}$ sodium $\beta$-glycerolphosphate and $3 \mathrm{mM} \mathrm{DTT}$ ) for $30 \mathrm{~min}$ at $30^{\circ} \mathrm{C}$. The samples were spotted on P81 papers, washed five times with $0.5 \%$ orthophosphoric acid, once with acetone and air dried. Radioactivity was quantified in a scintillation counter.

\section{Phosphorylation of elF2 $\beta$ by CK2 in vitro}

Phosphorylation of wild-type and mutant $\mathrm{His}_{6}-\mathrm{eIF} 2 \beta$ forms $\left(0.5 \mu \mathrm{g}\right.$ each) was carried out for $30 \mathrm{~min}$ at $30^{\circ} \mathrm{C}$ as described previously [16] in a medium containing 2 pmol of $\mathrm{His}_{6}-\mathrm{CK} 2$ holoenzyme (reconstituted by mixing $\mathrm{His}_{6}-\mathrm{CK} 2 \alpha$ and $\mathrm{His}_{6}-\mathrm{CK} 2 \beta$ at a 1:1 molar ratio) and $100 \mu \mathrm{M}\left[\gamma-{ }^{32} \mathrm{P}\right]$ ATP. The reactions were stopped by adding SDS/PAGE sample buffer and boiling, followed by SDS/PAGE and autoradiography. Coomassie Blue staining of the gel was performed to ensure equal amounts of protein in the assay. For phosphatase treatments, HA-eIF $2 \beta$ was immunoprecipitated and the immunocomplex was washed twice with phosphatase buffer $(50 \mathrm{mM}$ Tris/ $\mathrm{HCl}, \mathrm{pH} 7.5,100 \mathrm{mM} \mathrm{NaCl}$ and $1 \mathrm{mM} \mathrm{MgCl}_{2}$ ). Then 2 units of PP2Ac (catalytic subunit of PP2A) was added in a final volume of $35 \mu \mathrm{l}$ and incubated for 30 min at $37^{\circ} \mathrm{C}$. The immunocomplexes were centrifuged, washed three times with kinase buffer and subjected to CK2 phosphorylation as described above. Samples were loaded on to SDS/ $10 \%$ polyacrylamide gels and subjected to autoradiography.

\section{Two-dimensional gel electrophoresis}

HeLa cell extracts were precipitated with $10 \%$ ice-cold trichloroaceteic acid for $30 \mathrm{~min}$, centrifuged and washed with $100 \mathrm{mM}$ ammonium acetate in methanol. Pellets were resuspended in two-dimensional buffer (2.5\% Nonidet P40, 8.5 M urea, $0.8 \%$ ampholites and $100 \mathrm{mM}$ DTT). For the first dimension, samples were loaded on Immobiline dry strips ( $\mathrm{pH} 4-7)$ on a Multiphor II System $\left(\mathrm{LKB}^{\circledR}\right)$ and ran overnight at $1000 \mathrm{~V}$. For the second dimension, strips were equilibrated with $50 \mathrm{mM}$ Tris/ $\mathrm{HCl}$ (pH 8.8), $8.5 \mathrm{M}$ urea, $30 \%$ (v/v) glycerol and $2 \%$ (w/v) SDS for $30 \mathrm{~min}$ and applied on a SDS/polyacrylamide gel. After electrophoresis, samples were transferred on to PVDF membranes and developed with the indicated antibodies.

\section{RESULTS}

\section{Overexpression of elF2 $\beta$ leads to its phosphorylation at some but not all of its potential CK2 targeted sites}

CK2 has been considered to be involved in the basal phosphorylation of eIF $2 \beta$ from rabbit reticulocytes [21]. We decided to study this point in detail in HeLa cells by transfecting human eIF $2 \beta$ carrying the HA tag.

Transfection of HeLa cells allowed the expression of HAeIF $2 \beta$ to values $2-3$-fold above those of the endogenous eIF2 $\beta$ (Figure 1A). The HA-eIF2 $\beta$ form was recognized by the antiHA and the anti-eIF $2 \beta$ antibodies. It migrated slightly above the endogenous eIF $2 \beta$, as expected due to the presence of the HA tag. Moreover, the overexpressed HA-eIF $2 \beta$ was phosphorylated in vivo and immunoprecipitated with the anti-HA antibodies.

The ${ }^{32} \mathrm{P}$ incorporation into eIF $2 \beta$ purified from rabbit reticulocyte lysates catalysed in vitro by $\mathrm{CK} 2$ has been shown to be enhanced by prior dephosphorylation of $\operatorname{eIF} 2 \beta$ by either alkaline phosphatase or PP2A [21]. In order to explore if this also occurs in HeLa cells, HA-eIF $2 \beta$ from transfected HeLa cells was immunoprecipitated with the anti-HA antibody and the immunoprecipitate was subjected to phosphorylation by human recombinant CK2 holoenzyme. A parallel experiment was performed in which the immunoprecipitated HA-eIF2 $\beta$ was subjected to dephosphorylation with the PP2Ac followed by rephosphorylation with CK2 holoenzyme. The results showed that the untreated HA-eIF $2 \beta$ present in the immunoprecipitates was still phosphorylated by CK2, which suggests that the CK2-targeted sites are not completely phosphorylated in vivo (Figure 1B). Nonetheless, the increase in the extent of phosphorylation achieved in the samples of HA-eIF2 $\beta$ that had been subjected to prior dephosphorylation by PP2A indicated that at least some of these CK2 sites are phosphorylated in vivo.

\section{CK2 inhibitors block HA-elF2 $\beta$ phosphorylation in HeLa cells}

The results shown above support a role of CK2 in the basal phosphorylation of eIF $2 \beta$, but experimental evidence of its real involvement in this process in living cells was lacking. As a first approach to this question, we used chemical inhibitors of CK2. Apigenin and emodin are two structurally different compounds that have been shown to inhibit CK2 activity in cultured cells [16,39]. As expected from previous reports [16], treatment of HeLa cells with these compounds led to a decrease in the CK2 activity in the cell extracts (Figure 2A). At $40 \mu \mathrm{M}$, emodin decreased CK 2 by $60 \%$, whereas the inhibition caused by apigenin was 

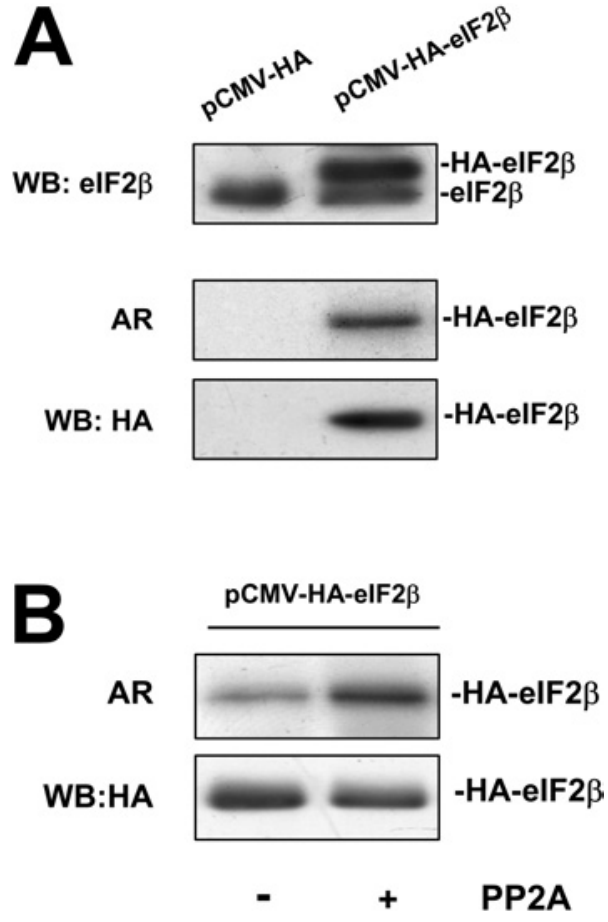

Figure 1 HA-elF2 $\beta$ is constitutively phosphorylated in HeLa cells

(A) HeLa cells were transfected with either pCMV-HA or pCMV-HA-elF2 $\beta$. Cell lysates were analysed by Western blotting with anti-elF2 $\beta$ antibody. In a parallel experiment, HeLa cells were labelled with $\left.{ }^{32} \mathrm{P}\right] \mathrm{P}_{\mathrm{i}}$ and cell lysates were immunoprecipitated with anti-HA antibody and subjected to SDS/PAGE followed by autoradiography (AR) and Western blotting against anti-HA antibody. (B) HeLa cells were transfected with pCMV-HA-elF2 $\beta$ and cell lysates were immunoprecipitated with anti-HA antibody. Immunoprecipitates were left untreated or dephosphorylated with PP2A catalytic subunit and re-phosphorylated with CK2 holoenzyme. Samples were subjected to SDS/PAGE followed by autoradiography (AR) and Western blotting against $\mathrm{HA}$ antibody to ensure equal amount of $\mathrm{HA}-\mathrm{elF} 2 \beta$ in the assay.

approx. $40 \%$. Addition of these inhibitors to HeLa cells at the onset of their labelling with $\left[{ }^{32} \mathrm{P}\right]$-phosphate caused a marked decrease in HA-eIF $2 \beta$ phosphorylation in vivo (Figure $2 \mathrm{~A}$, lower panels), without affecting the total HA-eIF2 $\beta$ levels. This effect is dose-dependent as shown in Supplementary Figure 1 (http://www.BiochemJ.org/bj/394/bj3940227add.htm).

\section{Overexpression of the wild-type or the dead mutant forms of CK2 $\alpha$ affects the phosphorylation of elF2 $\beta$ in HeLa cells}

The identity of CK 2 as an eIF $2 \beta$ kinase in vivo was also studied by co-transfecting HeLa cells with the vector encoding HA-eIF2 $\beta$ and pCMV plasmids encoding either the active catalytic subunit of CK2 $(\mathrm{CK} 2 \alpha)$ or its dominant inactive mutant (CK2 $\alpha$ K68A). Cell extracts transfected with either plasmid showed a 4-5-fold increase in CK $2 \alpha$ content (Figure 2B), but they did not alter the CK2 $\beta$ levels. A concomitant increase in CK2 activity in the model peptide substrate was observed in extracts from cells overexpressing pCMV-CK $2 \alpha$ wild-type, whereas the extracts from cells transfected with pCMV-CK $2 \alpha$ K68A did not show any significant change with respect to the control. This is in agreement with the data reported by others [38], in cells where overexpression of the kinase-dead mutants did not alter the activity in the extracts although it decreased the autophosphorylation of CK $2 \beta$ in vivo. Interestingly, the overexpression of CK $2 \alpha \mathrm{K} 68 \mathrm{~A}$ decreased the phosphorylation in vivo of HA-eIF $2 \beta$ to about one-half, whereas overexpression of CK $2 \alpha$ wild-type increased it by $2-3$-fold. These results strongly support the idea that CK2 is involved in the in vivo phosphorylation of eIF $2 \beta$.
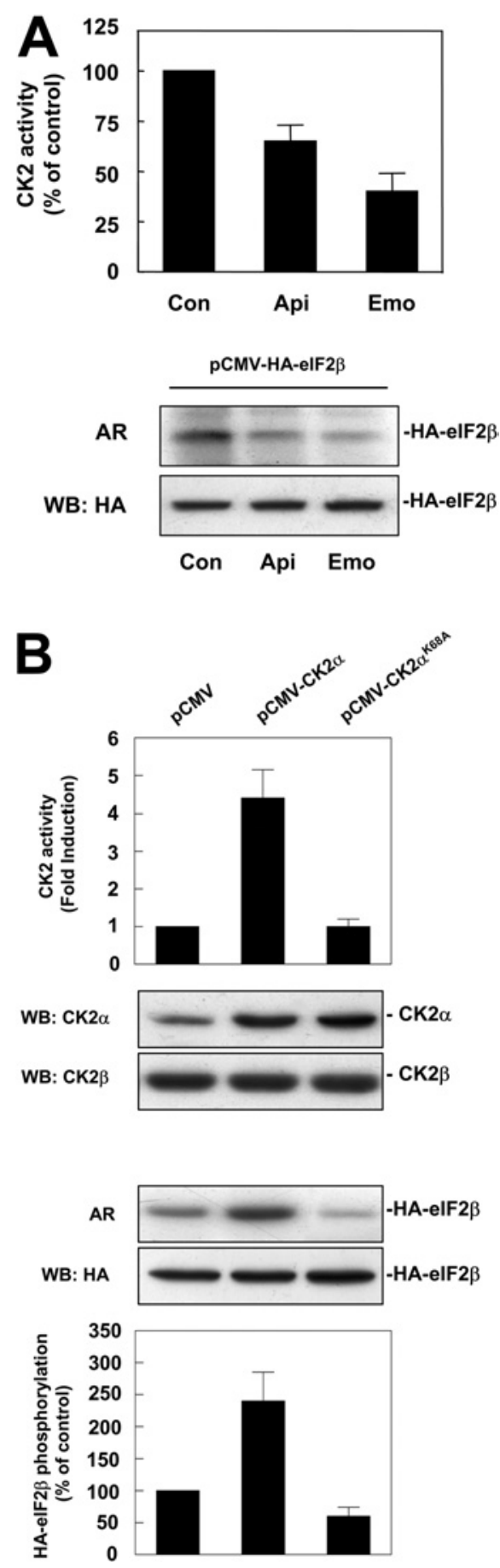

Figure 2 HA-eIF2 $\beta$ is phosphorylated by CK2 in HeLa cells

(A) pCMV-HA-elF2 $\beta$ transfected HeLa cells were labelled with $\left.{ }^{32} \mathrm{P}\right] \mathrm{P}_{\mathrm{i}}$ in the absence or presence of CK2 inhibitors apigenin and emodin $(40 \mu \mathrm{M})$ during the labelling time as indicated. An aliquot of cell lysate was tested for CK2 activity over CK2-specific peptide substrate RRRAADSDDDDD to monitor CK2 inhibition on the assay (upper panel). Samples were immunoprecipitated with anti-HA antibody and subjected to SDS/PAGE followed by autoradiography (AR) and Western blotting against HA antibody to ensure equal amount of HA-elF2 $\beta$ in the assay (lower panels). (B) HeLa cells were transfected with pCMV, pCMV-CK2 $\alpha$ or pCMV-CK2 $\alpha$ K68A and cell lysates were assayed for CK2 activity over CK2-specific peptide substrate RRRAADSDDDDD and subjected to Western blotting against CK2 $\alpha$ and CK2 $\beta$ antibodies (upper panels). In a parallel experiment, HA-elF2 $\beta$ was co-transfected with the CK2 $\alpha$ plasmids indicated above and HeLa cells were labelled with $\left.{ }^{32} \mathrm{P}\right] \mathrm{P}_{\mathrm{i}}$. Cell lysates were immunoprecipitated with anti-HA antibody and subjected to SDS/PAGE followed by autoradiography (AR) and Western blotting against HA antibody to ensure equal amount of HA-elF2 $\beta$ in the assay. Quantification of autoradiography is also shown in the graph (lower panels). 


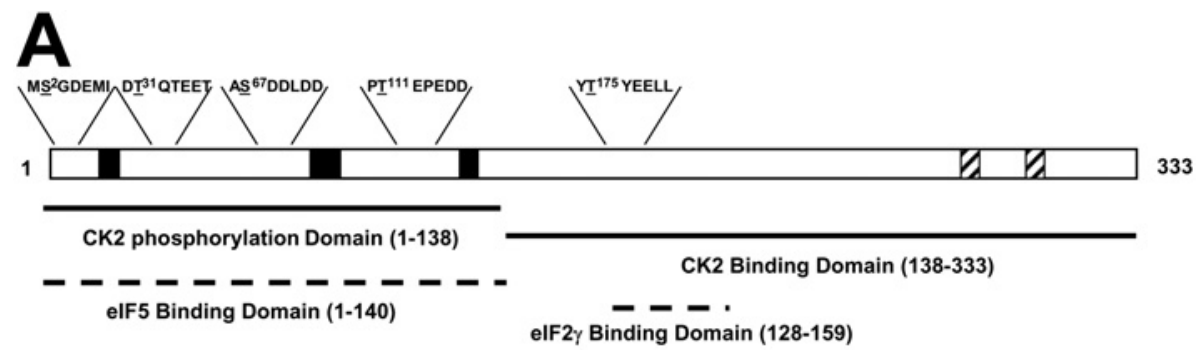

Poly-Lysine streches (14-21, 79-87, 124-129)

C $\mathrm{C}_{2}-\mathrm{C}_{2}$ Finger Domain (281-305)
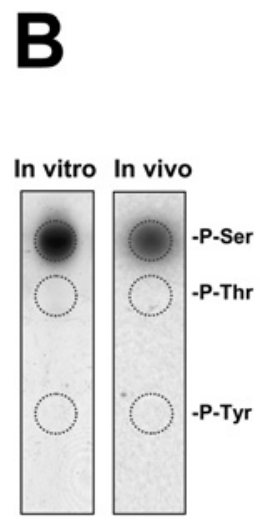
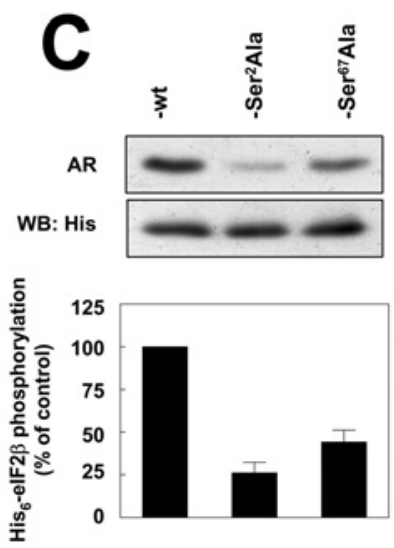
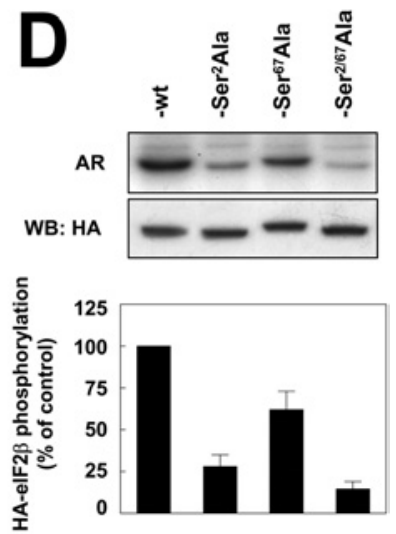

Figure 3 elF2 $\beta$ is phosphorylated in vitro and in vivo on $\operatorname{Ser}^{2}$ and Ser ${ }^{67}$

(A) Domain structure of elF2 $\beta$. Potential CK2 phosphorylation sequences are indicated over the sequence of the open box representing the polypeptide chain, and phosphorylation sites are underlined. Black boxes indicate polylysine stretches and shadowed boxes the $\mathrm{C}_{2}-\mathrm{C}_{2}$ finger domain. Black lines indicate the characterized domains for interaction and phosphorylation by $\mathrm{CK} 2$. Discontinuous lines indicate the location in human elF2 $\beta$ for binding to elF5 and elF2 $\gamma$ extrapolated from the data reported on yeast. (B) Phospho amino acid analysis of (left panel) His 6 -elF2 $\beta$ phosphorylated by CK2 holoenzyme resolved by SDS/PAGE and transferred on to PVDF membrane and (right panel) HA-elF2 $\beta$ from HeLa cells labelled with [32P]P, immunoprecipitated with anti-HA, resolved by SDS/PAGE and transferred on to PVDF membrane. In both cases, radioactive bands were excised from the membrane and the samples were analysed by one-dimensional high-voltage electrophoresis on a TLC cellulose plate and autoradiography. P-Ser, P-Thr and P-Tyr denote the positions of phosphoserine, phosphothreonine and phosphotyrosine respectively as determined by ninhydrin staining of standards. (C) Densitometry of the autoradiography of in vitro phosphorylation of His ${ }_{6}-\mathrm{elF} 2 \beta$, $\mathrm{His}_{6}-\mathrm{elF} 2 \beta \mathrm{S} 2 \mathrm{~A}$ and His ${ }_{6}-\mathrm{elF} 2 \beta \mathrm{S} 67 \mathrm{~A}$ by $\mathrm{CK}_{2}$ holoenzyme. Western blotting with anti-His 6 was carried out to ensure equal amount of protein in the assay. (D) In vivo phosphorylation of HA-elF2 $\beta, H A-e l F 2 \beta S 2 A, H A-e l F 2 \beta S 67 A$ and HA-elF2 $\beta$ S2/67A. Transfected HeLa cells were labelled with [ $\left.{ }^{32} \mathrm{P}\right] \mathrm{P}_{\mathrm{i}}$ and cell lysates were immunoprecipitated with anti-HA antibody and subjected to SDS/PAGE followed by autoradiography and Western blotting against HA antibody to ensure equal amount of HA-elF2 $\beta$ in the assay. Densitometries of the autoradiography are shown.

\section{CK2 phosphorylates human elF2 $\beta$ on $\operatorname{Ser}^{2}$ and $\operatorname{Ser}^{67}$}

In a previous study on human recombinant $\operatorname{eIF} 2 \beta$, we had observed that the CK2 holoenzyme-targeted sites in vitro were located within the N-terminal 138-residues segment of hr-eIF2 $\beta$ (where hr is human recombinant). As $1.25 \mathrm{~mol}$ of phosphate was incorporated per mol of eIF2 $\beta$, we concluded that hr-eIF2 $\beta$ must contain at least two CK2 sites [16]. $\mathrm{Ser}^{2}$ and $\mathrm{Ser}^{67}$ have been shown to serve as phosphorylation sites for CK2 in rabbit reticulocyte $\operatorname{eIF} 2 \beta$ [21]. The sequence corresponding to the phosphorylation site at $\mathrm{Ser}^{2}$ is conserved from human to chicken eIF2 $\beta$ (Figure 3A). The $\operatorname{Ser}^{67}$ site is also conserved in other mammals but is replaced by a threonine in the chicken sequence. None of these potential phosphorylation sites are present in Drosophila and yeast eIF $2 \beta$ sequences. Interestingly, $\operatorname{Ser}^{13}$, the site of phosphorylation by $\mathrm{PKC}$, is also conserved in vertebrates but not in the other species, whereas $\mathrm{Ser}^{218}$, the phosphorylation site for PKA [21], is conserved even in Drosophila, although it is absent from yeast.

As to the potential existence of other CK2 phosphorylation sites in the human $\operatorname{eIF} 2 \beta$, inspecting its sequence also evidenced the presence of $\mathrm{Thr}^{31}$, Thr ${ }^{111}$ and $\mathrm{Thr}^{175}$ which have an acidic residue at position +3 with no basic residues in between, which is typical of the consensus sequence for CK2 phosphorylation [15]. Thr ${ }^{111}$ appears to be unique to the human eIF $2 \beta$ sequence, whereas $\mathrm{Thr}^{31}$ is present in both human and chicken, but it is absent from the rabbit, rat and mouse sequences and $\mathrm{Thr}^{175}$ is conserved in all of these species except for yeast.

As a first approach to discerning which of these sites are phosphorylated in vivo, phospho amino acid analysis was performed. Only serine sites were phosphorylated in HA-eIF2 $\beta$ immunoprecipitated from HeLa cells incubated with $\left[{ }^{32} \mathrm{P}\right] \mathrm{P}_{\mathrm{i}}$ (Figure $3 \mathrm{~B}$ ). A similar result was obtained with hr-eIF $2 \beta$ phosphorylated in vitro with human recombinant CK2. These results delimitated the search for potential CK2 phosphorylation sites to $\mathrm{Ser}^{2}$ and $\mathrm{Ser}^{67}$ in the N-terminal region of eIF $2 \beta$.

The efficiency of $\mathrm{Ser}^{2}$ and $\mathrm{Ser}^{67}$ serving as phosphorylation sites in human eIF $2 \beta$ was studied first in vitro by using recombinant $\mathrm{His}_{6}$-tagged forms of eIF2 $\beta$ expressed in bacteria. As shown in Figure 3(C), Ser-to-Ala mutation at each one of these serine residues decreased the ability of $\mathrm{His}_{6}-\mathrm{eIF} 2 \beta$ to serve as substrate for CK2. However, the effect was more dramatic when $\operatorname{Ser}^{2}$ was mutated than with mutation at $\mathrm{Ser}^{67}$.

To discern if $\mathrm{Ser}^{2}$ and $\mathrm{Ser}^{67}$ are authentic phosphorylation sites and to determine if they are equally phosphorylated in vivo, a 
series of plasmids encoding HA-eIF $2 \beta$ mutants was constructed. HeLa cells transfected with these plasmids were metabolically ${ }^{32} \mathrm{P}$-labelled and the extracts were subjected to immunoprecipitation with anti-HA antibodies. The results showed that phosphorylation of the S2/67A double mutant was less than $20 \%$ that of wild-type HA-eIF2 $\beta$ (Figure 3D). This confirmed Ser $^{2}$ and $\mathrm{Ser}^{67}$ as the prevalent phosphorylation sites in vivo, although some other minor sites must exist in HA-eIF2 $\beta$. Phosphorylation of the single S67A mutant was lower than that of wild-type HA-eIF2 $\beta$, whereas the S2A mutant was markedly reduced. Taken together, the results pointed to $\mathrm{Ser}^{2}$ as a preferred phosphorylation site for CK2, whereas phosphorylation at $\operatorname{Ser}^{67}$ would be less prevalent.

It is worth noting that mutation at $\mathrm{Ser}^{67}$ did not alter the electrophoretic mobility of HA-eIF2 $\beta$ in SDS/PAGE, whereas mutation at $\mathrm{Ser}^{2}$, either alone or in combination with mutation at $\mathrm{Ser}^{67}$, caused a slight but consistent increase in its mobility. This would point to phosphorylation at $\operatorname{Ser}^{2}$ as one of the factors that contributes to the anomalous behaviour of eIF $2 \beta$ in gel electrophoresis.

\section{Phosphorylation of elF2 $\beta$ in HeLa cells is affected by serum and okadaic acid}

Previous reports have shown that in HeLa cells, endogenous eIF2 $\beta$ gives rise to different spots when analysed by two-dimensional gel electrophoresis [40]. The presence of several spots is indicative of the coexistence of in vivo forms of eIF $2 \beta$ with different phosphorylation levels. On the other hand, serum stimulation has been reported to provoke the conversion of these forms into a single form, but whether this involves conversion into a defined, specifically phosphorylated form of eIF $2 \beta$ or its complete dephosphorylation has not been established yet. As a first step towards approaching this question, we decided to monitor the changes in the phosphorylated forms of the endogenous eIF $2 \beta$ in HeLa cells subjected to serum deprivation, re-addition of $10 \%$ $(\mathrm{v} / \mathrm{v})$ serum or asynchronously growing. Moreover, since PP2A is potentially involved in eIF2 $\beta$ dephosphorylation [21], we decided to study the effect of okadaic acid, a well-known inhibitor of PP1 and PP $2 \mathrm{~A}$, on the eIF $2 \beta$ response to serum stimulation. In serumdeprived HeLa cell extracts, eIF $2 \beta$ is present mainly in three forms that differ in their $\mathrm{pI}$; the less prominent one corresponds to that with a more acidic pI (Figure 4). Addition of $10 \%$ serum shifted the pattern towards the more basic $\mathrm{pI}$ range and led to the more acidic spot decreasing and to a marked decrease in the intermediate form. The effects of serum stimulation were not observed in HeLa cells pretreated with okadaic acid. These results confirmed that phosphorylation of eIF $2 \beta$ is a dynamic process and supports the potential involvement of PP1/PP2A-type phosphatases in this process.

\section{Ser $^{2}$ is constitutively phosphorylated in human elF2 $\beta$}

In order to gain a deeper insight into the contribution of the CK2 sites to the phosphorylation status of eIF $2 \beta$ in HeLa cells, the immunoprecipitates obtained from serum-starved HeLa cells transfected with either wild-type or mutant forms of HA-eIF2 $\beta$ were subjected to two-dimensional gel electrophoresis analysis. A set of three spots was specifically detected with the anti-HA antibodies in the samples of HeLa cells overexpressing wildtype HA-eIF2 $\beta$ (Figure 5). The most prominent ones were spots denoted as 2 and 3 . This pattern was similar to that detected with the endogenous eIF $2 \beta$ under similar conditions, which evidenced that the overexpressed HA-eIF $2 \beta$ form behaved like the endogenous one and validated the approach used. Mutation at $\mathrm{Ser}^{67}$ did not significantly affect the pattern of spots but, in contrast

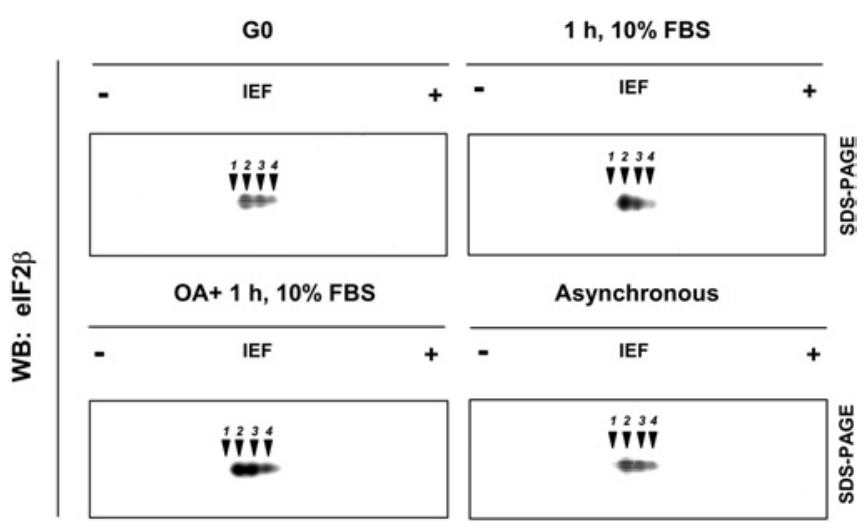

Figure 4 Phosphorylation of elF2 $\beta$ in HeLa cells is affected by serum and okadaic acid

HeLa cells were serum-starved for $24 \mathrm{~h}$ with $0.5 \%$ serum and left untreated (G0), re-stimulated for $1 \mathrm{~h}$ with $10 \%$ serum ( $1 \mathrm{~h}, 10 \% \mathrm{FBS})$, re-stimulated for $1 \mathrm{~h}$ with $10 \%$ serum in the presence of okadaic acid $(1 \mu \mathrm{M})(\mathrm{OA}+1 \mathrm{~h}, 10 \% \mathrm{FBS})$ or left in $10 \%$ FBS as the normal growth conditions (Asynchronous). Equal amounts of cell extract protein were precipitated in $10 \%$ trichloroacetic acid, subjected to two-dimensional electrophoresis as described in the Experimental section and developed with anti-elF2 $\beta$ antibodies. Spot localization is indicated by numbers over arrowheads. The experiment was performed three times with similar results. WB, Western blot; IEF, isoelectric focusing.

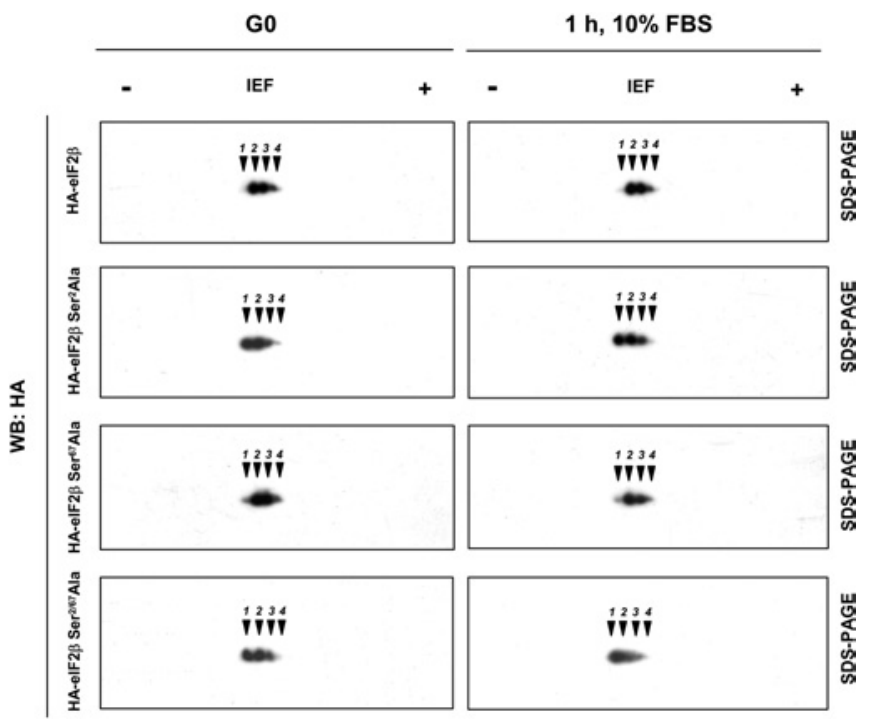

Figure $5 \mathrm{Ser}^{2}$ is constitutively phosphorylated in human elF2 $\beta$

HA-elF2 $\beta, H A-e l F 2 \beta S 2 A, H A-\mathrm{elF} 2 \beta$ S67A and HA-elF2 $\beta$ S2/67A transfected HeLa cells were serum-starved for $24 \mathrm{~h}$ with $0.5 \%$ serum and left untreated (G0) or re-stimulated for $1 \mathrm{~h}$ with $10 \%$ serum ( $1 \mathrm{~h}, 10 \% \mathrm{FBS}$ ). Equal amounts of cell extracts were precipitated in $10 \%$ trichloroacetic acid, subjected to two-dimensional electrophoresis as described in the Experimental section and developed with anti-HA antibodies. Spot localization is indicated by numbers over arrowheads. The experiment was performed three times with similar results. WB, Western blot; $\mathrm{IEF}$, isoelectric focusing.

with this, mutation at $\mathrm{Ser}^{2}$ provoked the appearance of a new spot with a more basic pI value, and in fact it shifted the whole pattern of the spots to higher pIs. The S2/67A double mutant behaved like the S2A mutant. Taken together, the results indicate that almost all eIF $2 \beta$ subunits are constitutively phosphorylated at $\mathrm{Ser}^{2}$ in vivo, whereas phosphorylation at $\mathrm{Ser}^{67}$ and other additional sites is restricted to a limited number of eIF $2 \beta$ subunits.

Next, we asked if re-adding $10 \%$ serum to starved HeLa cells would alter the phosphorylation pattern of HA-eIF2 $\beta$. No major 
changes in this pattern were observed with wild-type HA-eIF2 $\beta$ (Figure 5). These results are consistent with the idea that the phosphorylation state of $\mathrm{Ser}^{2}$ and $\mathrm{Ser}^{67}$ does not decrease in response to serum stimulation, whereas some of the additional phosphorylation sites would become dephosphorylated. This agrees with the activity pattern of CK2, which is constitutively active and increased in nuclear fraction after serum re-stimulation but presented minor changes in cytoplasmic and membrane fractions where almost all the cellular eIF $2 \beta$ protein is located (see Supplementary Figure 2 at http://www.BiochemJ.org/bj/394/ bj3940227add.htm).

Since previous reports have shown that mutation at CK2 phosphorylation sites affected the half-life of $\mathrm{I} \kappa \mathrm{B} \alpha$ (inhibitory $\kappa \mathrm{B} \alpha$ ) [41] and CK2 $\beta$ [42], we decided to test if mutation at $\mathrm{Ser}^{2}$ and $\mathrm{Ser}^{67}$ affected the stability of eIF $2 \beta$. Pulse-chase experiments in transfected HeLa cells showed that the $\operatorname{Ser}^{2}$ and $\mathrm{Ser}^{67}$ double mutant form of HA-eIF2 $\beta$ decayed with a half-life similar to that of the wild-type (see Supplementary Figure 3 at http:// www.BiochemJ.org/bj/394/bj3940227add.htm). This argues against phosphorylation having a role at $\mathrm{CK} 2$ sites in the stability of HA-eIF $2 \beta$ in these cells.

\section{The elF2 $\beta$ S2/67A mutant was incorporated into the elF2 trimer and associates with CK2 and elF5 in vivo}

The ability of the mutant protein to form the eIF2 trimer and to become integrated into typical complexes of eIF2 $\beta$, such as those with eIF5 [9] or with CK2 $\alpha$ [16], was also studied. The incorporation of the HA-eIF $2 \beta$ forms into eIF2 trimer was monitored by the presence of eIF $2 \alpha$ and eIF $2 \gamma$ in the immunoprecipitates obtained from transfected cells (Supplementary Figure 4 at http://www.BiochemJ.org/bj/394/bj3940227add.htm). As observed in Figure 6, the S2/67A double mutant form of HAeIF $2 \beta$ was incorporated into the eIF2 trimer as efficiently as the HA-eIF $2 \beta$ wild-type. The association between HA-eIF $2 \beta$ and either eIF5 or CK $2 \alpha$ was also studied. The presence of either eIF5 or CK $2 \alpha$ in the pellets immunoprecipitated with anti-HA antibodies, obtained from HeLa cells overexpressing the double mutant, was similar to that detected in cells overexpressing HAeIF $2 \beta$ wild-type. This indicates that the double phosphorylation site mutant retained the ability to bind to these proteins as efficiently as the wild-type form of $\operatorname{eIF} 2 \beta$.

\section{Ser $^{2}$ and Ser $^{67}$ are necessary for sustaining protein synthesis at a high rate}

Since eIF2 may participate in different stages of translation initiation, we decided to use an assay for global protein synthesis in transfected HeLa cells in order to evaluate the effects of the overexpression of the wild-type and mutant forms of eIF $2 \beta$. Moreover, we decided to extend this study by exploring the effects of the overexpression of an N-terminal truncated form of eIF2 $\beta$ lacking residues $1-137$, herein designated as HA-eIF2 $\beta$-CT. In a previous work, we observed that this truncated form was able to bind to CK2 but it was not a substrate for this protein kinase [16]. To standardize the assay conditions, the HeLa cells were serum-starved for $24 \mathrm{~h}$ and then stimulated with $10 \%$ FBS after adding the $\left.{ }^{35} \mathrm{~S}\right]$ methionine/cysteine mixture. As shown in Figure 7(A), the overexpression of wild-type HA-eIF2 $\beta$ did not essentially affect the initial rate of protein synthesis, whereas the expression of HA-eIF $2 \beta$-CT caused a decrease in the rate of protein synthesis to approx. $50 \%$. The expression of the double mutant form of HA-eIF $2 \beta$ slowed down the rate of protein synthesis to values intermediate of those observed with wild-type and HA-eIF $2 \beta$-CT.

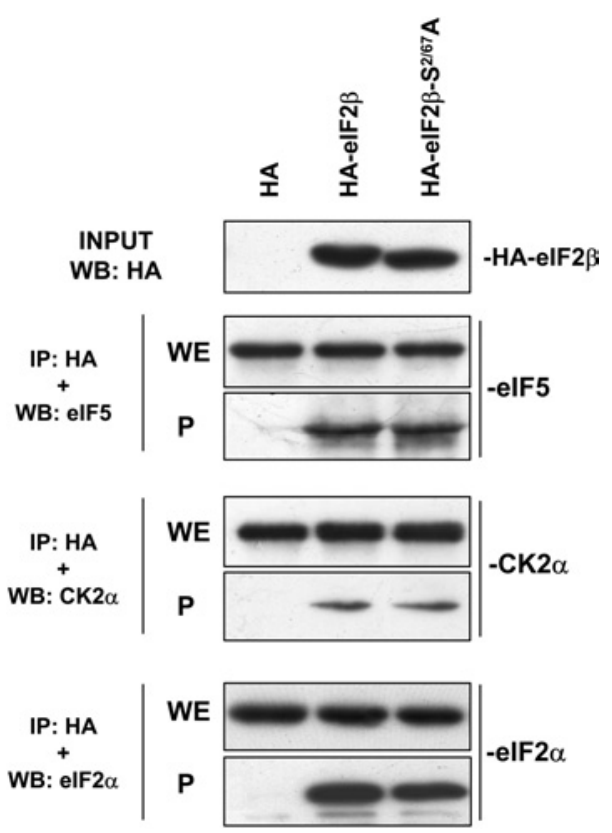

Figure 6 HA-elF2 $\beta$ and CK2 phosphorylation mutant HA-eIF2 $\beta$ S2/67A associates with elF5, CK2 $\alpha$ and elF2 $\alpha$

HeLa cells were transfected with pCMV-HA, pCMV-HA-elF2 $\beta$ and pCMV-HA-elF2 $\beta$ S2/67A and cell lysates were subjected to immunoprecipitation with anti-HA antibody. Immunoprecipitates (P) and an aliquot of the whole cell extract (WE) were subjected to SDS/PAGE, transferred on to PVDF membranes and developed with antibodies against elF5, CK2 $\alpha$ and elF2 $\alpha$ as indicated. The top panel indicates the input used for the assay. IP, immunoprecipitation.

\section{Overexpression of the $\mathrm{N}$-terminal truncated form of elF2 $\beta$ is highly deleterious to HeLa cell viability}

Inhibition of protein synthesis by different agents induces cell death. As the overexpression of the double phosphorylation sites mutant and the N-terminal truncated forms of eIF2 $\beta$ decreased protein synthesis to different levels, we decided to test if these changes affected cell viability. To this end, HeLa cells were transfected with increasing amounts of the vectors encoding the HA-eIF $2 \beta$ wild-type, the double phosphorylation sites mutant or for HA-eIF $2 \beta$-CT. After $48 \mathrm{~h}$ of culture in complete media, the number of living cells was counted. A parallel experiment was performed in which total cell extracts were obtained and used to monitor the expression levels of the different eIF $2 \beta$ forms. As shown in Figure 7(B), the overexpression of HA-eIF2 $\beta$ caused a small effect on cell viability, with a $15 \%$ decrease in the cell number at the highest dose of transfection tested. This effect could be due to competition effects between the endogenous eIF $2 \beta$ and the HA-eIF $2 \beta$ overexpressed to high levels for binding to other cellular factors that could affect the interaction of functional eIF2 contained in the $43 \mathrm{~S}$ pre-initiation complex as suggested by others [43]. The increase in cell death was slightly more evident in cells transfected with the HA-eIF2 $\beta$ S2/67A mutant, and became particularly marked in those overexpressing the HAeIF $2 \beta$-CT form. In fact, the toxic effects of the HA-eIF $2 \beta$-CT form were clearly detectable at doses where HA-eIF2 $\beta$ S2/67A was ineffective. It is worth noting that in our experiments, a range of $25-30 \%$ of the immunoprecipitated HA-eIF2 $\beta$, HA-eIF2 $\beta$ S2/67A and HA-eIF2 $\beta$-CT contains endogenous eIF $2 \alpha$ and eIF $2 \gamma$, which indicates that part of the overexpressed protein is incorporated into the eIF2 holoprotein (Supplementary Figure 4 at http://www.BiochemJ.org/bj/394/bj3940227add.htm). Taken together, these results suggest that the effects observed in protein 

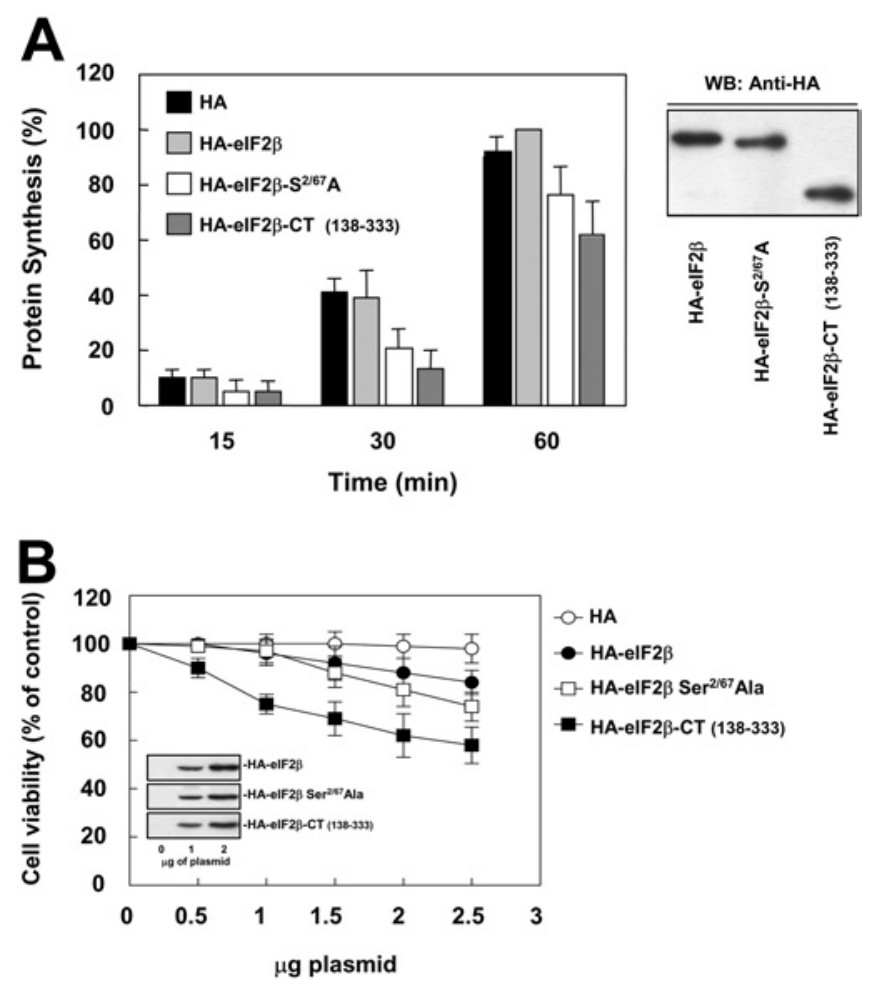

Figure 7 Mutation of CK2 phosphorylation sites on HA-elF2 $\beta$ impairs protein synthesis at a high rate but has minor effects on cell viability

(A) HeLa cells were transfected with pCMV-HA, pCMV-HA-elF2 $\beta$, pCMV-HA-elF2 $\beta$ S2/67A and pCMV-HA-elF2 $\beta(138-333)$ and serum-starved for $24 \mathrm{~h}$. Then cells were re-stimulated with $10 \%$ FBS in the presence of ${ }^{35}$ S $]$ methionine/cysteine for the indicated times. Cell extracts were analysed for radioactivity incorporation as indicated in the Experimental section. Radioactivity was expressed taking the maximum value as $100 \%$. An aliquot of samples were subjected to Western blotting with anti-HA antibody to ensure equal expression levels of transfected proteins on the assay. (B) HeLa cells were transfected with increasing amounts of pCMV-HA, pCMV-HA-elF2 $\beta$, pCMV-HA-elF2 $\beta$ S2/67A or pCMV-HA-elF2 $\beta$ (138-333), and after $48 \mathrm{~h}$ of transfection, cell viability was analysed using the MTT [3-(4,5-dimethylthiazol2-yl)-2,5-diphenyl-2H-tetrazolium bromide] assay. Cell viability was expressed taking the maximum value as $100 \%$

synthesis and cell viability could not be attributed to a decreased fraction of eIF2 holoprotein or to a cytotoxic effect of HA-eIF2 $\beta$ overexpression by itself.

\section{The N-terminal truncated form of elF2 $\beta$ binds to elF2 $\alpha$ but not to elF5}

The marked differences between HA-eIF2 $\beta$-CT and HA-eIF2 $\beta$ wild-type or S2/67A double mutant in protein synthesis and cell viability prompted us to study if they could be due to a defect in the ability of HA-eIF $2 \beta$-CT to associate with other cellular components. In a previous study, we demonstrated that eIF $2 \beta$-CT was able to bind to $\mathrm{CK} 2 \alpha$ as efficiently as eIF $2 \beta$ [16].

The immunoprecipitation technique was also used to study the incorporation of HA-eIF2 $\beta$-CT into the eIF2 trimer and its potential interaction with eIF5. The results shown in Figure 8(A) evidenced that HA-eIF $2 \beta$-CT was able to bind to endogenous eIF $2 \alpha$ as efficiently as HA-eIF $2 \beta$ wild-type. In contrast, a marked difference was observed concerning the binding to eIF5, since this factor was not detected in the immunoprecipitates from cells overexpressing HA-eIF2 $\beta$-CT, although eIF5 was clearly detected in the immunoprecipitates from cells overexpressing HA-eIF2 $\beta$ wild-type or the S2/67A mutant. To ensure that the $\mathrm{N}$-terminal domain of eIF2 $\beta$ was responsible for eIF5 binding,
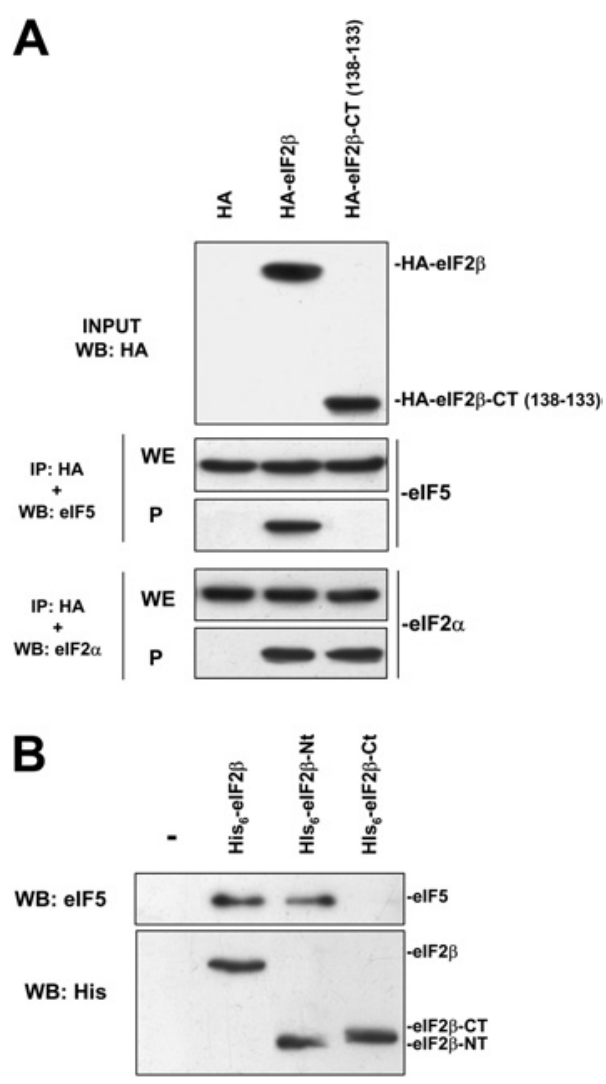

Figure 8 N-terminal deletion mutant HA-elF2 $\beta$ (HA-elF2 $\beta$ 138-333) does no associate with elF5

(A) HeLa cells were transfected with pCMV-HA, pCMV-HA-elF2 $\beta$ and pCMV-HA-elF2 $\beta$ (138-333) and cell lysates were subjected to immunoprecipitation with anti-HA antibody. Immunoprecipitates (P) and an aliquot of the whole cell extract (WE) were subjected to SDS/PAGE, transferred on to PVDF membranes and developed with antibodies against elF5 and elF2 $\alpha$ as indicated. The top panel indicates the input used for the assay. (B) $\mathrm{His}_{6}-\mathrm{elF} 2 \beta$, $\mathrm{His}_{6}-\mathrm{elF} 2 \beta \mathrm{CT}$ (138-333) or $\mathrm{His}_{6}-\mathrm{elF} 2 \beta \mathrm{NT}$ (1-137) was incubated with $500 \mu \mathrm{g}$ of HeLa cell extract. A slurry of Ni-NTA-agarose $(1: 1 ; 20 \mu \mathrm{l})$ was added to recover recombinant proteins and elF5 bound to $\mathrm{His}_{6}$-tagged proteins was analysed by SDS/PAGE and Western blotting with anti-elF5 antibody (upper panel). An aliquot of the experiment was analysed by SDS/PAGE and Western blotting using anti-His ${ }_{6}$ antibody to ensure equal amount of recombinant protein in the assay (lower panel).

pull-down experiments using different recombinant eIF $2 \beta$ forms were carried out. As shown in Figure 8(B), $\mathrm{His}_{6}-\mathrm{eIF} 2 \beta$ and $\mathrm{His}_{6}-$ eIF $2 \beta$-NT (1-137), but not $\mathrm{His}_{6}-\mathrm{eIF} 2 \beta$-CT (138-333), bind to eIF5 from HeLa cell extracts.

Taken together, these results support the notion that the $\mathrm{N}$ terminal region of human eIF $2 \beta$ does not participate in its integration into the eIF2 trimer as reported previously for yeast eIF2 [9]. Moreover, they also show that the N-terminal region is absolutely required for its binding to eIF5 in vivo, as observed previously by others in in vitro assays [10]. In addition, the inability to bind eIF5 might provide an explanation for the marked effects of the overexpression of HA-eIF $2 \beta$-CT on protein synthesis.

\section{DISCUSSION}

Phosphorylation of eIF2 by CK2 in vitro is unusual because in yeast and in invertebrates it takes place specifically in its eIF $2 \alpha$ subunit, although in residues different from the equivalent of $\operatorname{Ser}^{51}$ [29], whereas in mammals it occurs exclusively in its $\operatorname{eIF} 2 \beta$ subunit $[3,21]$. Although different lines of in vitro 
evidence pointed to $\mathrm{CK} 2$ being potentially involved in eIF2 $\beta$ phosphorylation in living cells, no studies on the real involvement of CK2 in this process using in vivo approaches have been undertaken to date. Our present results combining in vitro studies with purified CK2 and experiments in vivo designed to alter CK2 activity demonstrate that CK2 is really involved in the in vivo phosphorylation of eIF $2 \beta$. Previous reports based on the overexpression of mutated forms of mammalian $\operatorname{IF} 2 \mathrm{~B} \varepsilon$ (the catalytic subunit of eIF2B) [35] and eIF5 [44] have shown that these translation initiation factors are also phosphorylated in vivo at CK2 sites. Moreover, experiments in yeast using strains that express either the wild-type form or the temperature-sensitive catalytic subunit of CK2 showed the involvement of CK2 in the in vivo phosphorylation of eIF5 [45]. However, to our knowledge, the present paper is the first report showing that changes of CK2 activity in vivo alter the phosphorylation of a translation initiation factor in mammalian cells.

Our results show that $\mathrm{Ser}^{2}$ and $\mathrm{Ser}^{67}$ are the main CK2 phosphorylation sites in human eIF $2 \beta$. These sites are located at the $\mathrm{N}$-terminal extension of eIF $2 \beta$ characteristic of eukaryotes but absent from Archaea, a region that also harbours the lysine stretches, or lysine boxes, present in yeast and mammals. The absence of the CK2 phosphorylation sites in this N-terminal region of yeast and invertebrate eIF $2 \beta$ indicates that the CK2 phosphorylation sites were incorporated during evolution and are probably required in mammals. However, the functional meaning of the CK2-catalysed eIF $2 \beta$ phosphorylation has never been firmly established. Our results show that mutation of $\mathrm{Ser}^{2}$ and $\mathrm{Ser}^{67}$ to alanine residues impairs the properties of this subunit. It must be emphasized that these effects are not due merely to an exacerbated increase in the eIF $2 \beta$ protein since the defect was not observed in cells overexpressing the wild-type form of eIF $2 \beta$ to similar levels. The decrease in the rate of protein synthesis was not due to a loss of incorporation into the eIF2 trimer, as indicated by the presence of eIF $2 \alpha$ and eIF $2 \gamma$ in the complexes with either wildtype or S2/67A mutant forms of eIF $2 \beta$, or to a defect in binding to eIF5. It is then conceivable that the lack of phosphorylation at the positions corresponding to $\operatorname{Ser}^{2}$ and $\operatorname{Ser}^{67}$ might alter the conformation of the N-terminal region of eIF $2 \beta$ required for its proper participation in translation initiation at a step beyond the interaction with eIF5.

The importance of the phosphorylation at $\mathrm{Ser}^{2}$ can be specially inferred from the data supplied by the two-dimensional maps, which indicate that almost all of the cellular eIF $2 \beta$ subunit is constitutively phosphorylated at this site. Constitutive phosphorylation at $\mathrm{Ser}^{67}$ has been reported previously for the rabbit eIF2 $\beta$ subunit [21]. Our results agree with the idea that a significant fraction of the total HA-eIF $2 \beta$ is also phosphorylated at $\mathrm{Ser}^{67}$, and this phosphorylation can also be considered as constitutive as it did not change upon serum stimulation.

Another interesting observation in our present study is that besides being phosphorylated at $\operatorname{Ser}^{2}$ and $\operatorname{Ser}^{67}$, human eIF2 $\beta$ is also phosphorylated at other sites, and the phosphorylation at least in some of these sites decreases in response to serum. Moreover, the presence of several spots in the samples from the double phosphorylation site mutant suggests that phosphorylation at the two CK2 sites does not seem to be hierarchical to the phosphorylation at the other sites.

The N-terminal region of eIF $2 \beta$ is unique to eukaryotes, but its central/C-terminal regions show a high homology to the archaeal $\operatorname{aIF} 2 \beta$, the latter resembling an $\mathrm{N}$-truncated form of $\operatorname{eIF} 2 \beta$. The $\mathrm{N}$-terminal region of yeast eIF $2 \beta$ is dispensable for binding of this subunit to eIF $2 \gamma$. The residues involved in this binding are located at the central domain of $\operatorname{eIF} 2 \beta$. This interaction is crucial for assembling the eIF2 trimer because no direct eIF $2 \beta-\mathrm{eIF} 2 \alpha$ binding seems to occur [19]. Our results agree with the idea that the N-terminal region is not involved in assembling the eIF2 as HA-eIF $2 \beta$-CT was incorporated into complexes with eIF $2 \alpha$ as efficiently as the HA-tagged wild-type form of eIF $2 \beta$.

Previous studies in yeast have shown that the N-terminal domain of eIF $2 \beta$ is crucial for its interaction with the catalytic subunit of eIF2B (eIF2B $\varepsilon$ ) and with eIF5 [9]. Interaction with the latter seems especially important for the formation of the multifactor complex as it enhances the binding of eIF5 to the NIP1/ eIF3c [12]. In vitro studies using recombinant proteins corresponding to human $\operatorname{eIF} 2 \beta$ deletion mutants showed that the interaction with eIF5 requires the lysine boxes in the N-terminal domain of $\operatorname{eIF} 2 \beta[9,10]$, but the possibility that other sequences neighbouring the second lysine box are also involved in eIF5 binding has been suggested for yeast [7]. Our results show that mutation at $\mathrm{Ser}^{2}$ and $\mathrm{Ser}^{67}$, which are located in the acidic sequences preceding the first and the second lysine boxes, does not seem to affect eIF $2 \beta$-eIF5 binding. On the other hand, our results support the notion that the binding sites for eIF5 are located exclusively in the N-terminal region of eIF $2 \beta$.

The effects of the overexpression of HA-eIF $2 \beta-\mathrm{CT}$ on protein synthesis inhibition and HeLa cell death were more marked than those caused by the overexpression of similar levels of the double phosphorylation site mutant. In this context, it is worth noting that previous studies in yeast have observed that deleting the regions corresponding to the three lysine blocks in eIF $2 \beta$ compromise yeast growth [7], but no data concerning mammalian cells are available to date. Our results indicate that the loss of eIF5 binding observed with HA-eIF2 $\beta$-CT can be at least one of the factors that underlie the marked effects on protein synthesis and decrease in mammalian cell survival.

In previous studies, we had observed that eIF2 forms complexes with $\mathrm{CK} 2$ and their interaction involves direct contacts between the central/C-terminal regions of eIF2 $\beta$ (eIF2 $\beta$-CT) and the catalytic subunit of $\mathrm{CK} 2(\mathrm{CK} 2 \alpha)$ [16]. The coimmunoprecipitation of CK2 $\alpha$ with HA-eIF2 $\beta$ agrees with the existence of these interactions. Moreover, the lack of effect caused by mutation at the $\mathrm{CK} 2$ phosphorylation sites at the $\mathrm{N}$-terminal region of $\operatorname{eIF} 2 \beta$ was in agreement with the idea that this region does not contribute to this binding [16]. This would leave the $\mathrm{N}$-terminal region of eIF $2 \beta$ accessible to bind to other initiation factors when assembling the different complexes formed during the translation initiation process. Thus the simultaneous binding of eIF $2 \beta$ to $\mathrm{CK} 2 \alpha$ and other eIFs cannot be disregarded. At this point, it is worthwhile recalling that eIF5 [44], the catalytic subunit of eIF2B $(\mathrm{eIF} 2 \mathrm{~B} \varepsilon)$ [35], and some of the subunits of eIF3 [46] are substrates for CK2. Therefore such a binding might help to locate CK2 in the close vicinity of certain specific substrates. It is tempting, as a result, to speculate that the overexpression of HAeIF $2 \beta$-CT could interfere with the formation of some of these complexes, such as the eIF5-eIF $2 \beta-\mathrm{CK} 2 \alpha$ complex, and might contribute to the cytotoxic effects that this causes in HeLa cells.

We are grateful to Dr S. Bartolomé (LAFEAL-UAB-Barcelona) for gel scanning and Figure presentation, and to Dr S. Mackenzie (Universitat Autònoma de Barcelona) for criticisms and corrections of the language. This work was supported by grants SAF2002-03239 from MCYT (Ministero de Ciencia y Tecnología) and 2001SGR00199 from DGR (Direccío General de Recerca) (GENCAT), Spain.

\section{REFERENCES}

1 Preiss, T. and Hentze, M. W. (2003) Starting the protein synthesis: eukaryotic translation initiation. BioEssays 25, 1201-1211

2 Kapp, L. D. and Lorsh, J. R. (2004) The molecular mechanisms of eukaryotic translation. Annu. Rev. Biochem. 73, 657-704 
3 Kimball, S. R. (1999) Eukaryotic initiation factor elF2. Int. J. Biochem. Cell Biol. 31, 25-29

4 Krishnamoorthy, T., Pavitt, G. D., Zhang, F., Dever, T. E. and Hinnebusch, A. G. (2001) Tight binding of the phosphorylated $\alpha$ subunit of initiation factor 2 (elF2 $\alpha$ ) to the regulatory subunits of guanine nucleotide exchange factor elF2B is required for inhibition of translation initiation. Mol. Cell. Biol. 21, 5018-5030

5 Thompson, G. M., Pacheco, E., Melo, E. 0. and Castilho, B. A. (2000) Conserved sequences in the $\beta$ subunit of archaeal and eukaryal translation initiation factor 2 (elF2), absent from elF5, mediate interaction with elF2 $\gamma$. Biochem. J. 347, 703-709

6 Nika, J., Rippel, S. and Hannig, E. M. (2001) Biochemical analysis of the elF2 $\beta \gamma$ complex reveals a structural function for elF2 $\alpha$ in catalyzed nucleotide exchange. J. Biol. Chem. 276, 1051-1056

7 Laurino, J. P., Thompson, G. M., Pacheco, E. and Castilho, B. A. (1999) The $\beta$ subunit of eukaryotic translation initiation factor 2 binds mRNA through the lysine repeats and a region comprising the C2-C2 motif. Mol. Cell. Biol. 19, 173-181

8 Kimball, S. R., Heinzinger, N. K., Horetsky, R. L. and Jefferson, L. S. (1998) Identification of interprotein interactions between the subunits of eukaryotic initiation factors elF2 and elF2B. J. Biol. Chem. 273, 3039-3044

9 Asano, K., Krishnamoorthy, T., Phan, L., Pavitt, G. D. and Hinnebusch, A. G. (1999) Conserved bipartite motifs in yeast elF5 and elF2B $\varepsilon$, GTPase-activating and GDP-GTP exchange factors in translation initiation, mediate binding to their common substrate elF2. EMBO J. 18, 1673-1688

10 Das, S., Maiti, T., Das, K. and Maitra, U. (1997) Specific interaction of eukaryotic translation initiation factor 5 (elF5) with the $\beta$-subunit of elF2. J. Biol. Chem. 272 31712-31718

11 Valasek, L., Nielsen, K. H. and Hinnebusch, A. G. (2002) Direct elF2-elF3 contact in the multifactor complex is important for translation initiation in vivo. EMBO J. 21, 5886-5898

12 Singh, C. R., Yamamoto, Y. and Asano, K. (2004) Physical association of eukaryotic initiation factor (elF) 5 carboxyl-terminal domain with the lysine-rich elF $2 \beta$ segment strongly enhances its binding to elF3. J. Biol. Chem. 279, 49644-49655

13 Kebache, S., Zuo, D., Chevet, E. and Larose, L. (2002) Modulation of protein translation by Nck-1. Proc. Natl. Acad. Sci. U.S.A. 99, 5406-5411

14 Kebache, S., Cardin, E., Nguyen, D. T., Chevet, E. and Larose, L. (2004) Nck-1 antagonizes the endoplasmic reticulum stress-induced inhibition of translation. J. Biol. Chem. 279, 9662-9671

15 Meggio, F. and Pinna, L. A. (2003) One-thousand-and-one substrates of protein kinase CK2? FASEB J. 17, 349-368

16 Llorens, F., Roher, N., Miró, F. A., Sarno, S., Ruiz, F. X., Meggio, F., Plana, M., Pinna, L. A. and Itarte, E. (2003) Eukaryotic translation-initiation factor elF2 $\beta$ binds to protein kinase CK2: effects on CK2 $\alpha$ activity. Biochem. J. 375, 623-631

17 Pathak, V. K., Nielsen, P. J., Trachsel, H. and Hershey, J. W. (1988) Structure of the $\beta$ subunit of translational initiation factor elF-2. Cell (Cambridge, Mass.) 54, 633-639

18 Gutierrez, P., Osborne, M. J., Siddiqui, N., Trempe, J. F., Arrowsmith, C. and Gehring, K. (2004) Structure of the archaeal translation initiation factor alF2 $\beta$ from Methanobacterium thermoautotrophicum: implications for translation initiation. Protein Sci. 13, 659-667

19 Hashimoto, N. N., Carnevalli, L. S. and Castilho, B. A. (2002) Translation initiation at non-AUG codons mediated by weakened association of eukaryotic initiation factor (elF) 2 subunits. Biochem. J. 367, 359-368

20 Donahue, T. F., Cigan, A. M., Pabich, E. K. and Valavicius, B. C. (1988) Mutations at a $\mathrm{Zn}(\mathrm{II})$ finger motif in the yeast elF-2 $\beta$ gene alter ribosomal start-site selection during the scanning process. Cell (Cambridge, Mass.) 54, 621-632

21 Welsh, G. I., Price, N. T., Bladergroen, B. A., Bloomberg, G. and Proud, C. G. (1994) Identification of novel phosphorylation sites in the $\beta$-subunit of translation initiation factor elF-2. Biochem. Biophys. Res. Commun. 201, 1279-1288

22 Issinger, 0. G., Benne, R., Hershey, J. W. and Traut, R. R. (1976) Phosphorylation in vitro of eukaryotic initiation factors IF-E2 and IF-E3 by protein kinases. J. Biol. Chem. 251, 6471-6474

23 Benne, R., Edman, J., Traut, R. R. and Hershey, J. W. (1978) Phosphorylation of eukaryotic protein synthesis initiation factors. Proc. Natl. Acad. Sci. U.S.A. 75, 108-112

24 Ting, N. S., Kao, P. N., Chan, D. W., Lintott, L. G. and Lees-Miller, S. P. (1998) DNA-dependent protein kinase interacts with antigen receptor response element binding proteins NF90 and NF45. J. Biol. Chem. 273, 2136-2145

25 Duncan, R. and Hershey, J. W. (1984) Heat shock-induced translational alterations in HeLa cells: initiation factor modifications and the inhibition of translation. J. Biol. Chem. 259, 11882-11889

Received 14 April 2005/8 September 2005; accepted 14 October 2005

Published as BJ Immediate Publication 14 October 2005, doi:10.1042/BJ20050605
26 Duncan, R. and Hershey, J. W. (1985) Regulation of initiation factors during translational repression caused by serum depletion: covalent modification. J. Biol. Chem. 260, 5493-5497

27 Garcia, A. M., Martin, M. E., Blanco, L., Martin-Hidalgo, A., Fando, J. L., Herrera, E. and Salinas, M. (1996) Effect of diabetes on protein synthesis rate and eukaryotic initiation factor activities in the liver of virgin and pregnant rats. Biol. Neonate $\mathbf{6 9}$, $37-50$

28 Luis, A. M., Izquierdo, J. M., Ostronoff, L. K., Salinas, M., Santaren, J. F. and Cuezva, J. M. (1993) Translational regulation of mitochondrial differentiation in neonatal rat liver: specific increase in the translational efficiency of the nuclear-encoded mitochondrial $\beta$-F1-ATPase mRNA. J. Biol. Chem. 268, 1868-1875

29 Feng, L., Yoon, H. and Donahue, T. F. (1994) Casein kinase II mediates multiple phosphorylation of Saccharomyces cerevisiae elF-2 $\alpha$ (encoded by SUI2), which is required for optimal elF-2 function in S. cerevisiae. Mol. Cell. Biol. 14, $5139-5153$

30 van den Heuvel, J., Lang, V., Richter, G., Price, N., Peacock, L., Proud, C. G. and McCarthy, J. E. (1995) The highly acidic C-terminal region of the yeast initiation factor subunit $2 \alpha$ (elF-2 $\alpha$ ) contains casein kinase phosphorylation sites and is essential for maintaining normal regulation of GCN4. Biochim. Biophys. Acta 1261, 337-348

31 Mehta, H. B., Dholakia, J. N., Roth, W. W., Parekh, B. S., Montelaro, R. C., Woodley, C. L. and Wahba, A. J. (1986) Structural studies on the eukaryotic chain initiation factor 2 from rabbit reticulocytes and brine shrimp Artemia embryos: phosphorylation by the heme-controlled repressor and casein kinase II. J. Biol. Chem. 261, 6705-6711

32 Dholakia, J. N., Xu, Z., Hille, M. B. and Wahba, A. J. (1990) Purification and characterization of sea urchin initiation factor 2: the requirement of guanine nucleotide exchange factor for the release of eukaryotic polypeptide chain initiation factor 2-bound GDP. J. Biol. Chem. 265, 19319-19323

33 Benne, R., Wong, C., Luedi, M. and Hershey, J. W. (1976) Purification and characterization of initiation factor IF-E2 from rabbit reticulocytes. J. Biol. Chem. 251, 7675-7681

34 Singh, L. P., Arorr, A. R. and Wahba, A. J. (1994) Phosphorylation of the guanine nucleotide exchange factor and eukaryotic initiation factor 2 by casein kinase II regulates guanine nucleotide binding and GDP/GTP exchange. Biochemistry 33, 9152-9157

35 Wang, X., Paulin, F. E., Campbell, L. E., Gomez, E., O'Brien, K., Morrice, N. and Proud, C. G. (2001) Eukaryotic initiation factor 2B: identification of multiple phosphorylation sites in the $\varepsilon$-subunit and their functions in vivo. EMBO J. 20, 4349-4359

36 Oldfield, S. and Proud, C. G. (1992) Purification, phosphorylation and control of the guanine-nucleotide-exchange factor from rabbit reticulocyte lysates. Eur. J. Biochem. 208, 73-81

37 Singh, L. P., Denslow, N. D. and Wahba, A. J. (1996) Modulation of rabbit reticulocyte guanine nucleotide exchange factor activity by casein kinases 1 and 2 and glycogen synthase kinase 3. Biochemistry 35, 3206-3212

38 Lebrin, L., Chambaz, E. M. and Bianchini, L. (2001) A role for protein kinase CK2 in cell proliferation: evidence using a kinase-inactive mutant of CK2 catalytic subunit $\alpha$. Oncogene 20, 2010-2022

39 Channavajhala, P. and Seldin, D. C. (2002) Functional interaction of protein kinase CK2 and c-Myc in lymphomagenesis. Oncogene 21, 5280-5288

40 Duncan, R. and Hershey, J. W. (1985) Regulation of initiation factors during translational repression caused by serum depletion: abundance, synthesis, and turnover rates. J. Biol. Chem. 260, 5486-5492

41 Lin, R., Beauparlant, P., Makris, C., Meloche, S. and Hiscott, J. (1996) Phosphorylation of $\mid \kappa B \alpha$ in the $C$-terminal PEST domain by casein kinase II affects intrinsic protein stability. Mol. Cell. Biol. 16, 1401-1409

42 Zhang, C., Vilk, G., Canton, D. A. and Litchfield, D. W. (2002) Phosphorylation regulates the stability of the regulatory CK2 $\beta$ subunit. Oncogene $\mathbf{2 1}, 3754-3764$

43 Chiorini, J. A., Boal, T. R., Miyamoto, S. and Safer, B. (1993) A difference in the rate of ribosomal elongation balances the synthesis of eukaryotic translation initiation factor (elF)- $2 \alpha$ and elF-2 $\beta$. J. Biol. Chem. 268, 13748-13755

44 Majumdar, R., Bandyopadhyay, A., Deng, H. and Maitra, U. (2002) Phosphorylation of mammalian translation initiation factor 5 (elF5) in vitro and in vivo. Nucleic Acids Res. 30, $1154-1162$

45 Maiti, T., Bandyopadhyay, A. and Maitra, U. (2003) Casein kinase II phosphorylates translation initiation factor 5 (elF5) in Saccharomyces cerevisiae. Yeast 20, 97-108

46 Lin, W. J., Tuazon, P. T. and Traugh, J. A. (1991) Characterization of the catalytic subunit of casein kinase II expressed in Escherichia coli and regulation of activity. J. Biol. Chem. 266, 5664-5669 